\title{
LA REIVINDICACIÓN DE SAN JOSÉ EN LA MODERNIDAD TEMPRANA: LOS VILLANCICOS PARA LA CATEDRAL DE PUEBLA DE SOR JUANA DE 1690
}

\author{
Robin Ann Rice \\ Universidad Popular Autónoma del Estado de Puebla, Puebla, México \\ robinann.rice@upaep.mx
}

\section{RESUMEN/ ABSTRACT}

San José tuvo una enorme popularidad en la Nueva España, pero no había sido siempre un personaje bien dibujado y reverenciado. En la premodernidad se trastocó su casi imperceptible carácter en los Evangelios canónicos y se aprovecharon las fuentes legendarias y apócrifas para crear una versión negativa del patriarca. Por esto, cuando Sor Juana compuso su juego de villancicos para festejar al santo, tenía muchos temas que podría explotar: los legendarios premodernos y los relacionados con su figura reinventada. Por medio de un análisis de los villancicos para celebrar al Santo en 1690, se identifican las fusiones de estas dos tradiciones para subrayar las libertades que tomó la Décima Musa en el momento de componer este juego de villancicos.

Palabras clave: Sor Juana, villancicos, San José, Nueva España, fiesta barroca.

\section{The Acknowledgment of Saint Joseph in the Early Modern Period: Sor Juana's Carols} (1690) FOR THE CATHEDRAL OF PUEBLA

Saint Joseph was extremely popular in New Spain but he hadn't always been such a well defined and revered character. During premodernity his already imperceptible character in the canonical Scriptures was altered and certain apocryphal and legendary sources were exploited to create a negative version of the Patriarch. For this reason, when Sor Juana composed her set of villancicos to celebrate the Saint, she had many themes that she could take advantage of: the premodern legendary ones and those related to his reinvented figure. By means of an analysis of the carols to celebrate the Saint in 1690, the fusions of these two traditions are identified to underline the liberties that the Tenth Muse took when she composed this set of carols. 
KEYWORDS: Sor Juana, carols, Saint Joseph, New Spain, Baroque celebration.

Recepción: 29/11/2017

Aprobación: 11/05/2018

En la segunda mitad del siglo XVII, los villancicos dedicados a santos constituían una parte importante de la fiesta barroca novohispana. Entre 1676 y 1691, Sor Juana Inés de la Cruz redactó doce juegos de villancicos: seis se consagraron a temas marianos, dos a San Pedro Apóstol; y compuso uno por cada uno de los siguientes personajes: San Pedro Nolasco, la Navidad, San José y Santa Catarina. Presentados ante grandes auditorios, ávidos de entretenimiento, los juegos de villancicos se presentaron en "esos 'Maitines' cantados en las iglesias la víspera de las solemnidades religiosas" (Benassy 31) como fiestas patronales, la Concepción, la Anunciación, entre otras muchas. El producto final consistía en versos ingeniosos que explotan ciertas partes de las Escrituras y las convertían en escenas cómicas o cotidianas, a veces chocarreras. El juego más extenso y posiblemente más atrevido de la Décima Musa, en cuanto a su trato de temas sacros, es el que se designó en 1690, a San José en la Catedral de Puebla.

José, esposo de María, madre de Dios, era de los personajes sacros menos arriesgados para un juego de villancicos. En primer término, se había convertido en una de las figuras más simpáticas de la modernidad temprana católica, después de un largo periodo de ambigüedad e indiferencia. Era patrono de ciudades, fundaciones y catedrales, y su importancia como símbolo de castidad, lealtad, humildad, etc. creció a partir de la segunda mitad del siglo XVI, cuando nada menos que Santa Teresa de Jesús "le dedicó el primer monasterio de su renovación del Carmelo" (Cantera 37). Esta labor se hizo en Ávila en 1562, pero la advocación a San José llegó a la Nueva España antes: en 1555, el primer Concilio de México y Provincia declaró el patronazgo de San José sobre el "Arzobispado de México y Provincia", o sea, "se convirtió en el protector de la naciente Iglesia mexicana" (Sánchez 2). Poco después, en 1556, lo nombraron patrono de la Puebla de los Ángeles y "se le encomendó cuidarla contra las tempestades y los rayos", igual que México, que agregó también granizo (Sánchez 2). El Tercer Concilio de Trento decretó en 1585 que se celebraría la fiesta de San José el 19 de marzo con octava (Sánchez 2).

Los villancicos novohispanos del siglo XVII no se han examinado con detenimiento, y los de Sor Juana son escasos. Martha Lilia Tenorio (1999) dedicó un libro al estudio en general de los villancicos sorjuaninos, que sirve 
como base importante para acercarse a ellos. En cuanto a ciertas aproximaciones desde el ámbito de la música virreinal, son notables los estudios clásicos de Stevenson (1952, 1968 y 1974), la investigación de Tello (1996) y las de Long (1991, 1994, 2006). No obstante, estudios específicos dedicados al análisis literario son casi inexistentes. Por esto, uno de los objetivos de este estudio es analizar cómo un personaje con la singularidad de carácter de San José le permitió a la Décima Musa amenizar la fiesta dedicada a él en la catedral de Puebla en 1690 con su juego más extenso e ingenioso. Era el personaje ideal para el tono del villancico barroco "a lo faceto" (Benassy 31 ), pues no había prácticamente escenas bíblicas que lo incluyeran sustancialmente y no pronunció palabra alguna en los Evangelios canónicos, así que permitía la experimentación con un arquetipo borroso que procediera de leyendas y tradiciones, materiales como los Evangelios apócrifos y sus derivados. Además, San José no era la Virgen María, y había más tolerancia para bromas y otras insinuaciones cómicas con su persona. En este entendimiento, primero se analizará la imagen de San José en la premodernidad y cómo el texto aprovechó algunas de estas características más confusas en el juego de villancicos. Después, se hará un análisis de la materia prima temática que el texto utilizó para retratar al San José dignificado por medio de imágenes cómicas que rememoran algunos aspectos de su era oscura.

\section{LA IMAGEN DE SAN JOSÉ EN LA PREMODERNIDAD}

San José mereció escasas menciones en los Evangelios de Marcos y Lucas, textos en los cuales no pronunció palabra alguna y tuvo un papel insignificante. Con esta gran laguna de información, las noticias difundidas del personaje en la premodernidad provinieron de los Evangelios apócrifos, específicamente del Protoevangelio de Santiago ${ }^{1}$ y la Historia de José el

Los Evangelios apócrifos son una fuente invaluable de historia religiosa. En términos generales, los textos apócrifos sirvieron para aclarar imprecisiones y vacíos informativos en los Evangelios. En muchos casos, como el del Protoevangelio de Santiago, la intención fue reforzar algún "dogma en peligro" (Manzi y Grau-Dieckmann 24). Por ejemplo, en los Evangelios oficiales como Mateo, Marcos, Lucas y Juan, mencionan a los hermanos y las hermanas de Jesús, alusiones graves que ponen en peligro la virginidad de María, antes, durante y después del parto. El Protoevangelio de Santiago procuró aclarar este dogma amenazado y explica que "José era viudo y que tenía seis hijos de su primer matrimonio, a los que Jesús 
Carpintero $^{2}$, y tendieron a ser versiones detalladas o rectificadoras de los hechos (Cantera 39). Por esto, en la Edad Media, las características utilizadas para esbozar su persona, tanto en la liturgia como en el arte, se recogieron de estas fuentes y crearon una imagen desdibujada, a veces negativa, que se fue rectificando paulatinamente en la opinión popular a partir del siglo XV. $\mathrm{El}$ antecedente moderno temprano a su culto parece ser la bula de León X -papa de 1513 al 1521-que otorgó indulgencias en un lugar a los peregrinos "donde san José se ha aparecido junto a la virgen María (10 de agosto de 1519), llevando en brazos a Jesús" en Cotignac, Francia (Echeverri 74). Completamente reivindicado en el siglo XVI por el Concilio de Trento (15451563), se volvió una figura extremadamente divulgada y admirada. Si bien es cierto que los textos apócrifos subsanaron lagunas narrativas en los Evangelios oficiales, también es importante considerar que agregaron demasiados datos anecdóticos tal vez inverosímiles. Algunos Padres de la Iglesia, por ejemplo San Gerónimo (¿347?-420) los impugnan por “extravagantes y 'delirantes”” y los papas Dámaso (366-394) y Gelasio (492-496) subrayaron los sentimientos de Gerónimo por medio de ordenanzas ideológicas sobre ellos (Manzi y Grau-Dieckmann 31). Como decretaron Manzi y Grau-Dieckmann:

Ésta es justamente la clave de los apócrifos más populares: no muestran las reglas inalterables de la verdad, se conceden exageraciones, fantasías. En los apócrifos, la imaginación se permite volar, remontarse al mito. El pueblo raso, el fiel muchas veces ignorante, necesitaba apoyar su religiosidad en el mito para comprender aquellas enseñanzas que a menudo excedían su entendimiento, simple y espontáneo. (31)

Por esto, el Concilio declaró que la Vulgata latina fuera la única fuente auténtica para la enseñanza y la predicación de la revelación divina (Manzi y Grau-Dieckmann 31). En pleno siglo XVII era uno de los santos con

consideraba como sus hermanos por haberse criado con ellos" (Manzi y Grau-Dieckmann 27). El Protoevangelio de Santiago se compuso posteriormente a los Evangelios oficiales, cerca de 150 DC.

La Historia de José el carpintero pretende llenar los huecos narrativos en los primeros capítulos de Mateo y Lucas por medio de la elucidación de la vida y la muerte de San José. En el texto, el Patriarca es un viudo de avanzada edad con varios hijos. La Historia es una compilación de varias tradiciones concernientes a la Virgen María y la Sagrada Familia, seguramente compuestas en el Egipto bizantino a fines del siglo VI o inicios del siglo VII DC (Ehrman y Pleše 157-158). 
más devotos y dedicaciones de la época, pero aún estaban presentes en la conceptualización inconsciente de los fieles comunes los rasgos populares 'saneados' por el Concilio.

En 1690, Sor Juana Inés de la Cruz, escritora e intelectual novohispana, dedicó villancicos, en juegos de tres nocturnos, a San José que solemnizaron en la santa iglesia Catedral de la Puebla de los Ángeles, los maitines del

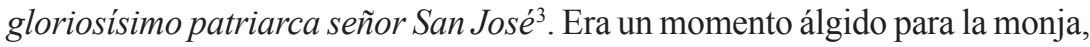
en aquel año había salido a la luz su polémica carta, Crisis de un sermón. Desde la llegada de los virreyes, Tomás de la Cerda y María Luisa Manrique, en 1680, y su regreso a España en 1687, Sor Juana había destapado su voz más pura y auténtica: eran los años de la redacción del Primer sueño y sus autos sacramentales. Era la favorita de la corte y sus obras se conocieron por los dos lados del Atlántico. Estaba en su plenitud poética y si ya se había caracterizado por intelectualmente atrevida antes, ahora lo era más ${ }^{4}$, cuando ya había caído en desfavor con los jerarcas eclesiásticos por la polémica Carta atenagórica. El atrevimiento intelectual asentado en el Sueño dio lugar a acciones concretas de osadía en sus escritos, y los villancicos aquí estudiados pudieran ser un ejemplo de ésta. El propósito de este escrito es revisar la imagen tradicional de San José antes de su 'reinvención' en la modernidad temprana y demostrar que los villancicos se pueden leer en dos niveles: uno en que secunda las opiniones de sus contemporáneos en cuanto a la 'reinvención' virtuosa de José, y otro en que manipula los atributos perjudiciales medievales del santo de manera intrépida y burlesca en otras partes del mismo texto. Por ser una figura tan reverenciada en el mundo hispano postridentino, era ineludible alabar al Patriarca en los villancicos: su virginidad, el ser ejemplar del amor sacrificado paterno, y su ascenso con su hijo, Jesús, al Paraíso. En contraste, la jerónima, fiel a su estilo, a veces, polivalente, podría jugar con aspectos atrevidos de su pasado más oscuro, como se verá más adelante, como son su mutismo, su papel -paragonado evasivamente en el texto con caracteres novohispanos marginales como el negro y el indio o incluso la feminización del santo- en el mundo pretridentino, de figura equívoca y confusa. Tal vez

3 Todas las citas del Villancico de 1690 son de Méndez Plancarte 1995.

$4 \quad$ Octavio Paz calculó que se había redactado el Primer sueño en 1685, pese a que no se publicó hasta 1692. Su explicación: "Debe de haber sido escrito alrededor de 1685 , cuando se acercaba a la cuarentena: es un poema de madurez, una verdadera confesión, en la que relata su aventura intelectual y la examina" (469). 
esta producción audaz se añadió a los otros eventos de 1690 para causar más problemas para Sor Juana con las autoridades eclesiásticas.

\section{VERSIONES PREMODERNAS DE LA VIDA DE SAN JOSÉ}

Según las versiones premodernas tanto escritas como iconográficas, en el momento de casarse con María, José era un anciano de 98 años de edad, viudo y con varios hijos; además tenía un "aspecto desaliñado y torpe" (Cantera 43). Sin devoción individual alguna hacia su persona, las representaciones plásticas de él eran siempre como un miembro de la Sagrada Familia. Al inicio, no hubo problemas porque todas estas características -su vejez y su compostura astrosa- se conjugaron para hacer más factible el estado virginal de la madre de Dios. Según la profecía de Isaías, cuando era el momento de buscar esposo para María, se reconocería la persona indicada de la siguiente manera: “"Un brote saldrá del tronco de Jesé, un vástago surgirá de sus raíces. Sobre él reposará el Espíritu de Yavé"” (cit. en Cantera 49). En las versiones medievales, San José regaña a María por su embarazo, pero las modernas tempranas demuestran al esposo dormido y avisado en sus sueños por un ángel que le declara que el padre del niño que espera María es el Espíritu Santo.

Cuando los Evangelios canónicos narran sobre la Natividad, pareciera que José estuviera al nivel de María en cuanto a las atenciones hacia el recién nacido. Sin embargo, en la Edad Media, representan a José como un viejo, "recostado o adormilado a causa de ser de noche y estar cansado por su ancianidad" (Cantera 62). En las escenas plásticas medievales de la Natividad, cualquier protagonismo pequeño que tuviera el padre del Niño Jesús se perdió por completo y lo representaron envilecido. El desprecio medieval hacia José provino, según Louis Réau, del Teatro de los Misterios, donde el santo fue representado como "un personaje de pocas luces, torpe, avaro y borrachín [...] [que] al ir a envolver al Niño en unos pañales y no haberlos encontrado, pretende hacerlo en sus calzones agujereados, o que vuelca el caldero de la sopa" (Cantera 65). Es en la adoración de los Reyes Magos que José se convierte en un personaje esquivo. Por un lado, en la traslación medieval lo retratan casi como un sirviente, "limitándose prácticamente a recoger los regalos que le hacían los magos, donde incluso se le representa fisgando con curiosidad dichos regalos, reforzando así el carácter vulgar con el que era tratado" (Cantera 71). 


\section{JOSÉ EN LA MODERNIDAD TEMPRANA}

Para poder reproducir plásticamente a José en la Edad Media, los artistas recurrieron a los textos apócrifos para resarcir las lagunas sobre su persona en los Evangelios canónicos. En la modernidad temprana, escritos legitimadores contribuyeron a la reinvención de San José. Uno de los primeros fue el del agustino francés Jean Gerson (1363-1429), cuyo poema intitulado "Josephina" recalcó las virtudes del santo, hasta aquel entonces no reconocidas (Cantera 40). Publicada en 1522 por el dominico milanés Isidoro de Isolano, la "Summa de donis Santi Joseph" ayudó a resaltar las virtudes de José y a promover su culto. Atraída quizás por estas "virtudes de obediencia, pobreza y castidad", Santa Teresa dedicó su primer monasterio de descalzas al santo como haría con doce más de sus diecisiete fundaciones (Cantera 41-42). En sus Conversaciones espirituales, San Francisco de Sales (1567-1622) ensalzó los poderes milagrosos del personaje. Como parte de su Flos Sanctorum (1616), el padre jesuita Ribadeneyra (1527-1611) realzó los dones de José: era seleccionado por Dios como padre de su Hijo y esposo de su Hija. En 1621, el Papa Gregorio XV pronunció la devoción del santo en toda la Iglesia el 19 de marzo (Cantera 43). Así que Sor Juana heredó una tradición higiénica del patriarca pero habrían perdurado también versiones legendarias.

\section{VILLANCICOS A SAN JOSÉ (1690), PUEBLA DE LOS ÁNGELES}

El villancico litúrgico era muy divulgado en las últimas décadas del siglo XVII $\mathrm{y}$, por ciertos textos que recriminan la evolución populachera del género, se puede llegar a ciertas conclusiones sobre sus características:

1) Que los villancicos se cantaban como parte de una ceremonia religiosa; 2) que esta fiesta fue adquiriendo cada vez más importancia en menoscabo de la ceremonia propiamente dicha (el Oficio Divino, litúrgico, tenía cada vez menos público, y los villancicos cada vez más; [...]); 3) que las celebraciones más comunes eran Navidad y Corpus Christi; 4) que se seguían usando divinizaciones ("hechos a imitación o en la letra o en el tono de los cantares o letras profanas"); 5) que los villancicos se ejecutaban con ciertas características de representación. (Tenorio 23) 
En la segunda mitad del siglo XVII, el villancico barroco llegó a su cenit y el género se caracterizó por su gran variedad y complejidad en cuanto a la métrica, los estribillos, y por la actitud sin cuidado de "entretejer el chiste vulgar con las presentaciones de algún misterio religioso o de algún pasaje de la Escritura" (Tenorio 29). Por esto, utilizar la virginidad de María como parte del ingenio cómico de los versos, o mencionar el mutismo de José o su negritud, son temas lícitos.

José no era un personaje desconocido para Sor Juana, quien redactó diversos textos dedicados a él. No obstante, los textos más sustanciales son los villancicos dedicados a él en 1690. De autoría inequívoca, son doce los juegos de villancicos de la monja, compuestos entre 1676 y 1691 y diez que Méndez Plancarte dictaminó como "atribuibles" y corresponden al periodo entre 1677 y 1692. Las obras están compuestas según "el esquema clásico de los tres nocturnos", cada uno con tres villancicos, salvo el último, que es de dos letras (villancicos) (Tenorio 65). San José es una de las dos excepciones, es el juego más extenso de su producción en este género, su tercer nocturno es de 6 villancicos. El tercer nocturno de Santa Catarina, 1691, contiene 5 letras.

Los tres nocturnos poseen una función constante en su producción villanciquera: el primer nocturno desarrolla "la narración y planteamiento del asunto", el segundo tiende a concentrarse en la exposición lírica, el tercero "a la fiesta" por medio de la comicidad popular (Tenorio 65). Los villancicos se cantaron en los maitines y se estructuraron de la misma manera: tres nocturnos compuestos de tres letras que, en el caso de los maitines, eran salmos (Paz 411). Es paradójico que, originalmente, el Breviario romano dictaba que se recitara el Te Deum al final de maitines que, en el caso de los villancicos, se sustituyó por la poca solemne ensalada. En grandes festividades, inmediatamente después de los maitines, se iniciaba la misa. En el juego dedicado a San José, el tercer nocturno termina con el villancico VIII, que es una ensalada compuesta por la jácara, juguete, indio y negro. Luego, inicia la misa, para la cual se compusieron cuatro villancicos más.

Hay una diferencia entre el tono de los villancicos a la Virgen y el de los villancicos a San José y a San Pedro, que Martha Lilia Tenorio explica como una diferenciación en el trato: "San José y San Pedro representan seres de carne y hueso, con debilidades y grandezas, por los que se puede sentir compasión y admiración, no veneración" (114n). Los textos bíblicos nunca resaltaron alguna equivocación o debilidad de la Virgen, mientras que hubo versiones de los dos santos que revelaron inconsistencias de carácter, especialmente durante su significación en la Edad Media. 
Sor Juana heredó una tradición favorable a San José de la modernidad temprana española, sin embargo, se evidencia un conocimiento de la otra versión borrosa y nada edificante del Patriarca. Si Santa Teresa, indudablemente la mujer religiosa más influyente de sus tiempos, tenía tanta devoción por el santo, una intelectual como Sor Juana tendría, por lo menos, una gran curiosidad por examinar la personalidad de José y, posiblemente, una simpatía por él. A fin de cuentas, es el santo por excelencia hogareño, servicial, humilde y portentoso por el papel que le fue asignado como mudo, no protagónico y casto. Además, faltaba información para poder dibujar al personaje y, sin obviar la gran estima del santo en el siglo XVII, Sor Juana tenía más libertad para retratarlo (Tenorio 130). Parece que la monja subrayó este pronunciamiento en su dedicatoria:

\section{Divino Josef: si son}

vuestras glorias tan inmensas, que ignorándolas ninguno, no hay alguno que las sepa. (vv. 1-4)

En otras palabras, no se sabe nada del personaje y la "copla final de la dedicatoria $[\ldots]$ se traba con la conclusión del último villancico de la serie" (Tenorio 131):

al menos merezca ser

índice de una fineza

que piensa de vuestras glorias

todo aquello que no piensa, (vv. 17-20)

Aunados a los primeros versos que declaran un vacío total de información sobre José, en estos que concluyen la dedicatoria, subraya que "estos villancicos son una muestra de mi amor [fineza] y de lo que pienso sobre ti, aunque en realidad no lo pienso" (Tenorio 131). Estos versos ambiguos, "se relaciona[n] con la última copla del juego" (Tenorio 131).

Yo no entiendo tan gran Santo;

de mi solamente sé

que desde luego detesto

todo lo que no sonare bien;

y estaré

a lo que corrija

Nuestra Santa Fe. (vv. 31-37) 
En el siglo XVII, la reputación de San José estaba remendada en contraste con la Edad Media, pero había más prestigio en lo imaginario colectivo que información basada en fuentes bíblicas o históricas. Por eso, estas líneas reflejan que quizás se cometió un error en algunas de sus conjeturas poéticas sobre el santo (Tenorio 131), pero que no sabe nada sobre él debido a la poca documentación 'oficial' y se hará todo lo posible para no cometer blasfemia. La "Dedicatoria" subraya los conocimientos expuestos en los Evangelios sobre el personaje: nada. Con la supresión definitiva, por parte del Concilio, de los apócrifos - que completaron los sendos vacíos de los oficiales-, la voz lírica se queja de que: "Yo no entiendo tan gran Santo".

\section{PRIMER NOCTURNO}

El texto se inicia de forma jocosa con el estribillo de dos coros que recrea con la narración de los puntos de vista del Cielo (gozos) -Coro 1.- y de la Tierra (dolores), -Coro 2.- que recuerdan a los "Dolores y gozos de San José" que se popularizaron entre los siglos XVI y principios del XVIII. En los "Dolores y gozos", cada dolor es, a la vez, también un gozo. Por ejemplo, el tercer dolor y gozo: "Ejecutor obediente de las leyes divinas, glorioso San José, la sangre preciosísima que el Redentor Niño derramó en su circuncisión os traspasó el corazón, pero el nombre de Jesús que entonces se le impuso, os confortó llenándoos de alegría". En el estribillo:

Coro 1. - ¡Ay, ay, ay, cómo el Cielo se alegra!

Coro 2. - Mas ¡ay, ay, ay, que se queja la Tierra!

$$
[\ldots]
$$

1. -El Cielo se alegra de que a José goza.

2. - Y porque lo pierde la Tierra, lo llora. (vv. 1-10)

Por medio de un lenguaje que proviene de la poesía popular -el uso del "¡Ay, ay, ay"- los autores enseñan "cuestiones serias de dogmática cristiana" (Krutitskaya 7). Todo recurso retórico tenía su función: "Recurrir a las prácticas de poesía de tipo popular les podía servir a los autores como una herramienta de enseñanza y convencimiento" (Krutitskaya 7). Como se anota arriba, el primer nocturno es de índole narrativa y plantea el asunto. Las coplas recogen el tema de los gozos y los dolores del santo y su paralelismo con el cielo y la tierra. Asientan y ramifican para mencionar más características 
del patriarca: unas que vienen de los evangelios canónicos y otros, de los apócrifos. Las coplas rezan:

2. - Como aun después de su muerte

la Tierra lo poseía,

y guardado lo tenía

en su calabozo fuerte,

siente más perder la suerte

cuando tanto bien la deja. (vv. 15-20)

El cuerpo fue sepultado y estuvo en posesión de la tierra hasta que Jesús lo liberó para que pudiera ascender al cielo. Según el padre Ribadeneyra:

No hay duda sino que este santísimo Patriarca está en el cielo en lugar eminentisimo: y algunos Doctores dizen, que está en cuerpo, y en alma; asi por no saberse donde está su cuerpo (y si estuviese en la tierra, no querria el Señor que estuviese escondido, y careciese de aquella honra que tienen otros menores Santos) como porque si los muertos que resucitaron después que Christo Nuestro Señor resucitó, $\mathrm{y}$ aparecieron a muchos en Ierusalem, subieron al cielo en cuerpo y en alma el dia de la Ascension con el mismo Señor (como muchos graves Doctores dizen) piadosamente se puede creer, que no negó el Hijo de Dios a su padre putativo este privilegio que a tantos otros concedió. (266)

Como los dolores y gozos de San José, y dado que un mismo evento puede ser interpretado como un dolor y un gozo a la vez, la subida al cielo del santo representa un dolor para la tierra y un gozo para el cielo. Este "tira y afloja" presentado en esta sección es una alegoría del estado incierto espiritual de José después de su muerte, pues, los Evangelios no mencionan ni cuándo ni cómo murió y, según la doctrina, por haber muerto antes de la Crucifixión, no accedería al Paraíso. La Historia de José el carpintero aclaró esta problemática. Según el texto apócrifo, la renuencia de Jesús de prometer a su padre durante su vida la inmortalidad, perturbó a los apósteles y es enmendado por un cuidado filial del destino postmortem del Patriarca. Reza el texto que, por instigación de Jesús, el alma fue entregada al cielo, y su cuerpo, preservado incorrupto (Ehrman y Pleše 157). Tal vez la contienda en el villancico demuestra graciosamente la tensión causada por esta imprecisión en las Escrituras, imprecisión ajustada en el texto apócrifo. Sigue la lid entre la tierra y el cielo; la primera sufre por la pérdida de lo que considera suyo: 
"Vara fértil de Jesé / que de mi vientre ha nacido" (vv. 31-32). Tierra arguye que el esposo de María saldrá del tronco de Jesé y que de aquellas raíces brotará el Espíritu de Yavé. La Décima Musa se ha basado en los Evangelios apócrifos para la siguiente parte. Para escoger un esposo para María, el Sumo Sacerdote convocó a los viudos y a los solteros descendientes de David con órdenes de llevarse una vara. Entre la multitud de galanes con sus varas, la vara de José emanó flores blancas y lo sobrevoló una paloma blanca. Dado que, según los apócrifos, José era un anciano, en realidad no quería ser el novio escogido e intentó escabullirse escondiendo su vara entre su ropaje, mientras otros pretendientes no aptos rompieron con ira sus varas por no ser seleccionados (Cantera 48-50). Con la reinvención de José durante la Contrarreforma, no se podría ocultar la vara como parte de la iconografía sobre el Patriarca porque se había vuelto un 'símbolo parlante', pero se resignificó, así que pasó a aludir a "la pureza de San José" (Cantera 50).

En la intervención del cielo, parece que el texto hace alarde del silencio de San José en los Evangelios, como se vio en la "Dedicatoria". Por su bajo perfil, según el villancico, el cielo recuerda que:

$$
\begin{aligned}
& \text { pues tan Ángel se mostró, } \\
& \text { que nunca a hablarle llegó } \\
& \text { ninguno que Ángel no fuese; } \\
& \text { ni que voz humana oyese } \\
& \text { ni en medio de su pena. (vv. 37-41) }
\end{aligned}
$$

En primer lugar, uno de los seres que dirigió palabras a José en los Evangelios canónicos es el arcángel San Gabriel, pues el esposo de María estaba planeando amonestar a la Virgen por su embarazo, y San Gabriel se le apareció en un sueño para confirmar que el niño que esperaba era de Dios y que José tenía que nombrarle "Jesús" (Cantera 57). En segundo lugar, como se ha comentado, San José no tiene un papel protagónico en los Evangelios canónicos para merecer articular palabra alguna. El texto subraya que el padre postizo de Jesús apenas tiene un papel en los evangelios y que la única vez en que conversan con él es para que no cometa alguna impropiedad. Además de su mutismo, los versos hacen alusión a que nadie le dirige palabra al patriarca, sino un ángel enviado para que no cometa algún improperio. Esto, que podría interpretarse en la modernidad temprana como virtud -el silencio como humildad-, es claramente tergiversado en los versos. Interpretado conjuntamente con la "Dedicatoria", aporta más evidencia a la naturaleza sombrosa de San José, según Echeverri, ya "desclasado de su papel de padre" (86). 
El segundo villancico no rememora más que un solo concepto, que es el de reivindicar la falta de importancia de José en los Evangelios canónicos, y de situarlo en el nuevo contexto enaltecido propio de los siglos XVI y XVII. Las coplas proponen un silogismo poético. Primero, declara que el santo es igual a un muerto por su virginidad y pureza:

$$
\begin{aligned}
& \text { si es José Virgen y Puro, } \\
& \text { y el Virgen no vive en carne, } \\
& \text { muerto está al mundo y bien puede } \\
& \text { como muerto reputarse. (vv. 13-16) }
\end{aligned}
$$

Segundo, según la ley de Dios, para poder engrandecer la estima de los que mueren sin hijos, la viuda puede resarcir la falta casándose con el hermano del difunto. Todos los hijos engendrados de la nueva pareja son descendientes tanto del difunto como del hermano desposado con la viuda.

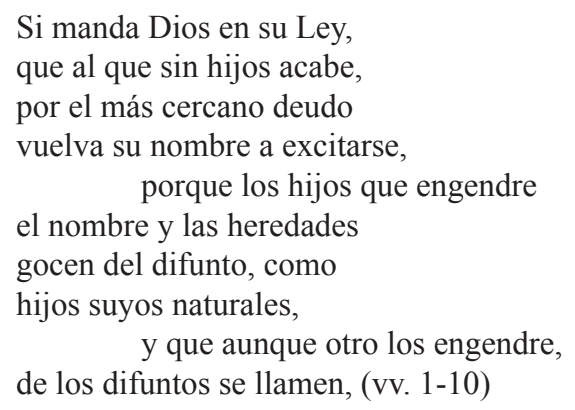

La lógica es que José es como un muerto por ser virgen. Dios, que es el hermano de todos los seres vivos, engendra a Jesús, que pertenece por ley como hijo a José y a Dios.

Tercero, la reputación de José es tan grandiosa que nada más él merece tener tal hijo:

¡Oh grandeza sin medida,

que sólo el Eterno Padre

le da su natural Hijo

para que suyo lo llame,

$[\ldots]$

Sépase, pues, de José, que es su perfección tan grande, que para ser Hijo suyo, sólo Cristo fue bastante. (vv. 21-32) 
El "Estribillo" resume el efecto de exaltación en cuanto al papel de San José en el plan de Dios:

¡Pues los Ángeles todos sus glorias canten, que no es mucho, si Cristo le llama Padre! (vv. 33-34)

Si en el "Villancico I" únicamente San Gabriel dirige palabra a San José y, por el otro lado, el Patriarca no conversa con persona alguna para el aumento de su santidad, el "Estribillo" del "Villancico II" declara que los ángeles no son capaces de alabarle suficientemente por ser el 'padre', según la ley, de Cristo.

A Sor Juana le cautivaban los debates sobre las finezas y otros tipos de disputas intelectuales, y en este villancico los personajes también discuten sobre la premisa presentada por el personaje 1. al inicio del texto en el "Estribillo": "¿Quién oyó lo que yo: / que el Hombre domine, y obedezca Dios?" (vv. 2-3). Los combatientes usan distintos argumentos para intentar comprobar que Dios obedece al ser humano. Como acató Méndez Plancarte:

Dios perdonó a súplicas de Moisés; [...] detuvo el Sol a ruegos de Josué, que "habló a Jehová y dijo... ¡Sol, detente en Gabaón...; y el Sol se detuvo" $[. .$.$] hizo retroceder diez líneas el cuadrante solar de$ Acaz, [...] dejó que su Ángel fuese vencido por Jacob, que por ello se llamó Israel, "el que peleó con Dios”. (421)

Los adversarios insisten en que Dios obedeció a Moisés, a Josué, a Acaz, a Jacob, a Elías, pero el personaje 1. porfía en que Dios concedió los deseos a estos personajes no por obediencia sino como muestra piadosa. Pero, en contraste con estas figuras bíblicas que Dios consintió, San José, de verdad, les excedió, porque "San José tuvo sujeto al Sol de Justicia y Fuego de Amor Divino, con la verdadera y propia obediencia filial que Cristo -en cuanto Hombre- le profesaba como a su Padre" (Méndez 421). Moisés, Josué, Acaz, etc. eran únicamente prefiguraciones debilitadas de José porque Cristo/Dios obedeció a su padre José con amor y acatamiento filial.

\section{SEGUNDO NOCTURNO}

El primer villancico de este nocturno justifica positivamente la particularidad perjudicial del silencio de José que se propagó negativamente en la Edad Media. Como se ha comentado arriba, en la Edad Media, el mutismo del 
santo en todos los evangelios oficiales contribuía a la caracterización de él como insensible, pasivo y torpe. En estos versos, el contrapunto se desarrolla entre Zacarías, que perdió por un tiempo la capacidad de habla como castigo, y José, que no pronunció palabra alguna por prudente. Cuando el Arcángel Gabriel le anunció a Zacarías que, pese su "edad caduca" (v. 4), sería padre con su esposa Santa Isabel de la Voz o San Juan Baptista, el anciano lo dudó. Como castigo por su desconfianza, el mensajero de Dios le proclama: "que en prisión de silencio / quede su lengua muda, / y hasta que la Voz nace, / la suya ni desata ni articula" (vv. 5-8). Por el otro lado, José: "sin verse, en la lectura / de la Sagrada Historia, / ni una palabra sola que él pronuncia?" (vv. 10-12). Así, en el villancico, el mutismo es una aseveración positiva, pero en la época premoderna, es interpretado como defecto.

Los versos entrelazan una argumentación contrastante perfectamente articulada entre los casos de Zacarías y de José. Zacarías se calló por castigo pero José por "industria / siendo mérito en uno / la señal misma que, en el otro, culpa" (vv. 14-16). La yuxtaposición prolongada entre Zacarías y José continúa cuando tacha al primero: "Por padre de la Voz, / aquél la voz añuda" (vv. 17-18); y alaba al segundo: "y por Padre del Verbo / éste, el hablar otra palabra excusa" (vv. 19-20). Jesús es el Verbo Eterno y José se enmudeció porque éste bastó por toda palabra. Las líneas rectifican, por medio de una reinterpretación, los aspectos negativos atribuidos a su persona:

\author{
Virgen y silencioso, \\ ni halaga ni fecunda \\ el tálamo, de prole, \\ ni el aire, de sus ecos con dulzuras. (vv. 25-28)
}

El "Estribillo" finaliza el villancico y resume todo: “¡Y así, todos entienden que José calla / porque el Verbo Divino es su Palabra!”.

El texto sucesivo sigue los Evangelios canónicos estrictamente. Todos los versos exaltan la virginidad tanto de José como de María, pero la atribuye más a una fineza demostrada por José, pues no solo se abstuvo él sino que también mantuvo casta a María.

Pues cualquiera Virgen, guarda sola en sí su candidez; 
mas José la guarda en sí y en la que su Esposa es.

El tener Dios Madre Virgen

le debe: pues a merced

lo fue de José, cediendo

su matrimonial poder. (vv. 5-12)

Las artes visuales medievales, que se basaron en los Evangelios apócrifos, enseñaron a un José ya anciano. Como se asentó anteriormente, la Historia de José el Carpintero asentó que José tenía 98 años cuando se casó con la Virgen María, era viudo y tenía varios hijos (Cantera 40): no era casto. Así que es claro que la jerónima se apegó a los Evangelios canónicos en este villancico.

El debate sobre las finezas de nuevo aparece en el juego de villancicos tal como aparece en varios escritos de la Décima Musa. El "Estribillo" jocoso presenta la incredulidad de dos personajes que observan: “¡Dios y Joséf apuestan!" (v. 11) y en las "Coplas" explica el motivo:

1. -Dios y José, parece
que andan a apuesta
sobre cuál ejecuta
mayor fineza. (vv. 15-18)

La red semántica es de términos económicos, de intercambio de bienes, como de una apuesta: "pago", "obsequio", "premie", "privarme", "compensarte", "servicio", "ventajas", como si la virginidad de María fuera un artículo de intercambio. Además, José y Dios conversan coloquialmente, de tú a tú, y la naturaleza del coloquio es bastante pedestre en cuanto a las referencias a la Virgen María:

con que a esa mesma

Señora, aunque es Casada, guardo Doncella.

2. -Dios dice: Ese obsequio

es bien te premie

con que, después del Parto,

Virgen te quede.

1. -Yo, de tener progenie

quise privarme,

para que Tú tuvieses

Virgen por Madre. (vv. 19-34) 
Después de rebatir sobre quién manifestó más y mayores finezas en cuanto a salvaguardar la virginidad de María, el diálogo se vuelve aún más corriente cuando José enfatiza su fineza por lo que le cuesta por ser de naturaleza celosa.

guardé el decoro,

1. - Yo a tu Madre Sagrada

que es la mayor fineza

para un celoso.

2. -Yo te hice el beneficio

de asegurarte,

que es, a quien tiene celos,

el Bien más grande.

1. -Yo te di, para Madre,

mi misma Esposa.

2. - Yo, para Esposa tuya,

mi Madre propia.

1. - Luego ninguno alcanza,

pues en la cuenta

tanto vale la paga

como la deuda. (vv. 47-62)

Parlamentar sobre la virginidad de María como un premio o un objeto de cambalache, incluir a un Dios que compite con José en cuanto a la comprobación de sus finezas, ostentar la protección de la virginidad física de María como un acto de generosidad, se combinan para crear una ambientación chusca en este movimiento del villancico.

\section{TERCERO NOCTURNO}

El tercer nocturno es de tono popular y festivo. El texto pondera el porqué "no de simple Virgen, / sino ligada a la unión / del Matrimonio consorcio, / el Hijo de Dios nació" (vv. 1-4). Prosigue a referirse a las tres razones que dio San Jerónimo, una explicación de san Ignacio de Antioquía y una quinta que provee la autora en dos partes. Primera, el único premio bastante digno para recompensar a José por su perfección fue el de ser el padre de Dios. Segunda, que la calidad de María no ameritó un "premio menor" (v. 24). Las dos partes de la argumentación forman un silogismo, algo que subraya la preferencia de la monja por la metodología tomista. 
El último villancico del nocturno antes de la misa es la ensalada, que funcionaba como " "fin de fiesta' de aquellas celebraciones litúrgicas de los maitines en las catedrales novohispanas" (Robinson 157). Como se mencionó anteriormente, la ensalada reemplazó el Te Deum prescrito por el Breviario romano. El texto se vuelve festivo con los cuatro textos que componen la ensalada: una jácara, un juguete, un indio y un negro. Esta ensalada obedece a la fisonomía literaria de sus tiempos. Se aprecia que es "una composición extensa que contiene un relato en el cual se van intercalando otros textos: versos de cancioncillas, de romances, rimas infantiles, refranes, adivinanzas, frases en latín [...]. Es una especie de juego poético-musical caracterizado por su variedad" (Tenorio 149). Méndez Plancarte explicó la jácara como:

jerga de los "matantes" o valentones andaluces, Cervantes usó "jácaros" por hampones [...] llamáronse sus romances, que loaban sus hazañas o imitaban su estilo; y aunque de la gente del hampa, y a menudo más que profano, el género alcanzó "gran popularidad" en todas las esferas sociales. [...] Sor Juana prolongó esa tradición, descollando en su típico desgarro hiperbólico y valentón, si bien estilizado y ennoblecido; (359-360)

Aprovecha los equívocos del léxico carpinteril para apuntalar a la vez al valentón y al humilde José. Por ejemplo, "mazo" que es herramienta típica de la profesión y también "hombre basto, rústico y grosero" (RAE). Explota la polisemia de "golpes", "obrador", etc.

Digo, pues (ya me acordé),

que este Oficial afamado

nunca gustó de colores, por lo que tienen de engaños. (vv. 23-26)

"Nunca gustó de colores," complementa los vv. 15-16 en que narra: "Érase un buen Carpintero / de éstos que labran en blanco,". Confronta los "colores" o afeites de las mujeres, que son "engaños" vilipendiados en la época, con el "Niño encarnado".

Verdad es, que en su Obrador

estaba un rico Sagrario con un Niño que no tuvo igual, de bien Encarnado. (vv. 27-30) 
“Obrador" significa el taller o el artífice o divino artífice, Dios. En el Sagrario -en la matriz de la Virgen María- estaba un Niño "bien Encarnado", por su color sano, o en el sentido sagrado.

El niño encarnado fue producto de un "Maestrazo" que "por cierta deuda / le dejó el Niño empeñado" (vv. 33-34). Pese a ser "Oficial", José no hizo el Niño, pero el Maestrazo -Dios-, por tener "cierta deuda" con él, se lo dejó empeñado. Quizás la "deuda" con la Humanidad por haber expulsado a Adán y Eva del Paraíso terrenal lo ha puesto en necesidad de dejar al "Niño empeñado" para pagar por el pecado original. Dios otorgó a José "la tutela / de un muy rico Mayorazgo" (vv. 41-42), pero se divierte con la pregunta de si Dios es su "Menor", ¿de qué tamaño sería él? Durante la reseña de los acontecimientos de su infancia, relata cuando Jesús se fue al Templo de Jerusalén y habló con los sabios, los cuales son llamados cómicamente "mentecatos" en la jácara. Al final, la materia prima de la broma es uno de los Dolores de San José:

Cátense aquí a mi Tutor

todo pena y sobresaltos, por saber que ha de morir su Menor ajusticiado.

$[\ldots]$

Señores Tutores, cuenta, los que son albaceazgos: si así le fué al que era bueno, ¿cómo les irá a los malos? (vv. 71-82)

El texto se permite agravios festivos en cuanto a los personajes sacros porque el género los posibilita.

Por cuanto al "Juguete", se trata de un sencillo acertijo para buscar la contestación correcta a la pregunta: “¿Cuál oficio San José / tiene?” (vv. 90-91). Según Tenorio, “La 'Ensalada de las adivinanzas' es quizá lo más cercano a la estructura de villancicos posteriores [...] Esta forma divinizada de preguntas-adivinanzas es muy didáctica" (44). Un personaje contesta que fue "Pastor" del "Cordero Pascual" (vv. 93-95). Otro, que fue "Labrador / de la Semilla mejor" (vv. 107-108). El tercero vaticina que fue "Carpintero" y que labró "el Madero / (Remedio de nuestro mal) / celestial" (vv. 125-140), o sea, la cruz. Nadie satisface a la pregunta y se rinden para obtener la respuesta:

Oficio es de Primera Clase, con el Rito más solemne, 


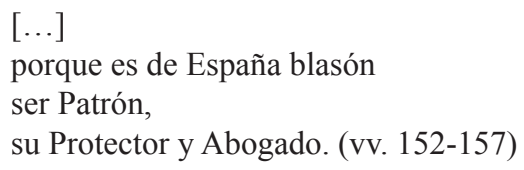

Se refiere al rezo litúrgico del Breviario Romano que "es de Primera Clase" -el oficio de San José- que invocan el día de su santo (Méndez 425).

El texto intitulado "Indio" retoca livianamente la técnica del anterior "Juguete" y formula también un acertijo. Divirtiéndose con la pronunciación típica y el español mezclado con el náhuatl, el personaje propone una adivinanza:

Yo también, quimati Dios, mo adivinanza pondrá, que no sólo los Dotore habla la Oniversidá. (vv. 165-168)

Formula el siguiente acertijo: “¿Cuál es mejor San José?”. Entre risas “¡Ja, ja, ja!” y otras interjecciones como " $i$ Gran disparate!” y “iTerrible!”, Indio asevera:

\author{
¿no ha visto en la Iglesia osté \\ junto mucho San José, \\ y entre todos la labor \\ de Xochimilco es mijor? (vv. 175-178)
}

Las tres intervenciones en la "Ensalada" son de personajes marginales. Indio quiere participar en el juego e introduce su punto de vista desde fuera. Conoce y ama una escultura de San José que se encuentra en un distrito indígena del México novohispano: Xochimilco. La mención, combinada con el acento y el léxico, personifican la variedad racial del pueblo novohispano. Además, desde su estado marginal, Indio se centraliza porque San José también pertenece a su pueblo en la forma de la imagen de Xochimilco que menciona y venera.

Negro también profiere desde la periferia, pues el texto mimetiza el hablar del negro novohispano ${ }^{6}$. Además, se atreve a sugerir que San José era negro, algo divulgado en los evangelios apócrifos:

6 Para una discusión de este recurso, ver: Porras, Jorge E., "Mexican Bozal Spanish in Sor Juana Inés de la Cruz's Villancicos: A Linguistic and Sociolinguistic Account”. Journal of Pan African Studies. Jul 2013, Vol. 6 Issue 1, pp. 157-170. 


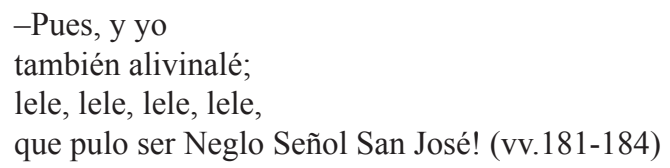

José es de la casa de David, como es Salomón, así que el texto alude a una versión del fragmento del Libro Primero de los Reyes. En el texto canónico, la Reina Sabá visitó al Rey Salomón para ver sus obras y ser testigo de su sapiencia. Sor Juana alude jocosamente a una versión espuria que sugiere que quizás tuvieron un romance -el Rey Salomón y la Reina Sabá- cuyo fruto fue un mestizo que denomina graciosamente un "cuarterón". En las Indias, el cuarterón fue el hijo de mestizo y española o viceversa, por tener un cuarto de indio y tres cuartos de español.

\author{
¿no pulo de Sabá \\ telé algún cualteló? \\ que a su Parre Salomó \\ también ella fue mujel: (vv. 186-189)
}

Como en el caso de Indio, la "Ensalada" admite al marginado como personaje. Su manera peculiar de habla se replica y, en el caso de Negro, también le faculta bromear sobre San José, Salomón y Sabá, puesto que insinúa un romance entre las figuras bíblicas e invoca a un José muy local, racialmente, un cuarterón. Lo que es notable y peculiar, y ayuda a dar una idea sobre la laxitud social con estas fiestas paralitúrgicas barrocas, es que la ensalada sustituyó el Te Deum en los Oficios Divinos en las fiestas especiales. Además, daba el auge para dar inicio a la misa, como se ve en la siguiente sección.

Es importante subrayar que los textos dramáticos áureos comúnmente incluyeron personajes 'marginales'. En el contexto novohispano, lo más común era la utilización de indios o negros, pero en otras obras o ámbitos también parodian vascos, portugueses y cualquier persona fuera de la cultura dominante. Es interesante que se incluya en esta lista de personajes periféricos a San José. Como se mofa de los acentos y los temas simples que tratan Indio y Negro, también San José se incluye en su categoría, dado que ni habla ni le hablan, aspectos que configuran un Patriarca bastante relegado. El juego de villancicos mantiene una narrativa que zigzaguea entre ortodoxa y peligrosamente heterodoxa. Si no fuera por la agudeza intelectual demostrada en la sutilidad irónica del manejo del balance perfecto de las historias canónicas y las apócrifas, legendarias y anecdóticas, si no fuera por 
las licencias poéticas permitidas en los villancicos, Sor Juana habría podido tener dificultades con sus propuestas literarias.

\section{PARA LA MISA}

Antes del inicio de las "Coplas", se registran las actitudes contrastantes entre Santo Tomás, quien dudó de la Resurrección de Cristo hasta poder tener evidencia sensible, por medio de la vista, de la crucifixión, y San José, quien creyó que el embarazo de María era virginal y prefirió no verlo, en el sentido de ignorarlo. Destaca que Tomás "quiere prueba hacer / de un Cuerpo sensible / a un Inmenso Sér" (vv. 16-18), mientras:

tiene tal poder,

Joséf en sus ojos

que viendo un Preñado,

duda cómo es. (vv. 20-23)

José no está exculpado: los Evangelios canónicos afirman que cuando vio a María embarazada, tenía planeado reprenderle clandestinamente. Sin embargo, el ángel Gabriel se le apareció en sus sueños y le reveló que el niño que esperaba su esposa era hijo de Dios. La autora llama la atención a esta falla en las coplas porque Dios tuvo que satisfacer "a Tomás con Carne / con Voz a José" (vv. 31-32).

Retoma el tema de la reacción del santo cuando vio a María embarazada y subraya de nuevo el sentido de la vista. Destaca la vista engañosa: "nunca estoy más ciego que / cuando veo" (vv. 19-20). Por desperdiciar su sentido de la vista:

\section{Viendo Dios que eran despojos sus ojos, de su sentir, hízole dormido abrir tantos ojos. (vv. 25-28)}

En tono recriminatorio:

Hablóle un Ángel glorioso, porque solo pudo ser bastante a satisfacer a un celoso. (vv. 29-32) 
Los dos defectos que ha destacado son extraídos de los Evangelios apócrifos: los celos y la necesidad de aplacarlos por medio de un mensajero angélico que notifica a José en sus sueños que el producto del embarazo es el hijo de Dios.

Los temas recurrentes en esta sección del texto son los celos de José por el embarazo de María y la paradoja del sueño que conduce a la verdad. Ciertas versiones enfatizan los celos de José, indicativos de una visión pretridentina. En la Edad Media, los retratos negativos del santo acentúan su enfado cuando descubrió a María embarazada. Tras el Concilio de Trento, y con las nuevas normas sobre las representaciones de los santos, ya no se figuraba reprochando a María sino dormido con la visitación del ángel que le reveló el linaje divino del bebé (Cantera 59). El texto se construye sobre la fe deficiente de José a quien Dios tuvo que mandar un ángel para avisarle de la causa del embarazo. Utiliza el topus áureo de la confusión entre vida y sueño:

¡Cuán contrario que anda Dios

del orden natural nuestro,

pues hace incierta la vista,

haciendo verdad el sueño! (vv. 14-17)

José es como el sujeto poético del Primer sueño, mientras esté dormido y sin los estorbos del cuerpo físico, es más perceptivo:

Despierto Joséf ignora, y dormido sabe: luego duerme cuando está velando, vela cuando está durmiendo. (vv. 19-22)

La autora conoce perfectamente bien que el conocimiento obtenido por medio de lo sensible es más obtuso que las imágenes fugaces del ser adormecido.

El texto cuestiona los motivos divinos por no avisar a José antes del embarazo -sobre la paternidad divina- para que no tuviera tantos celos, y propone dos respuestas, una de las cuales confirma como acertada. La primera es que quería "probarlo / con el dolor más acerbo", para que después gozara más del premio cuando supiera la verdad (vv. 35-38). Pero la mejor contestación es la siguiente: "El sentimiento de Dios / eran celos de su Pueblo" (vv. 43-44), idea expresada en Éxodo, y José tenía que ser la imagen de Dios en todos los sentidos.

Pues sienta él entre los Santos solamente este tormento; 
que es Padre de Cristo, y debe

parecerse al Padre Eterno. (vv. 47-50)

Los celos de José son una idea constante en la obra, hecho resaltado en la Edad Media, cuando el santo tuvo una mala reputación de iracundo.

El último villancico retoma el asunto de las finezas. Dios propone hacer un segundo Dios - Cristo- como una fineza a José. Pero resulta que no fue una fineza tan grande porque Cristo tuvo que obedecer y sujetarse a José y María. La voz poética habla en primera persona y juzga que:

Más sustentaba que Dios

a mi modo de entender, pues Dios lo sustenta todo, y él daba a Dios de comer; y tuvo, a fe, súbditos mejores, que Dios lo fue. (vv. 17-23)

La paradoja es que la fineza está en haber nombrado a José padre de Cristo. Por esto, como hijo, tuvo que ceñirse a las reglas de José y María. También, José lo mantuvo y, por esto, el súbdito es mejor que el que domina. La celebración concluye con la supuesta falsa modestia, pero tal vez la autora se refiere a conceptos pretridentinos que ha integrado en su celebración. Como se mencionó arriba, en ciertos momentos, el texto integra características del santo de la Edad Media antes de su reformulación en el siglo XVI.

\author{
Yo no entiendo tan gran Santo; \\ de mí sé \\ que desde luego detesto \\ lo que no sonare bien; \\ y estaré \\ a lo que corrija \\ Nuestra Santa Fe. (vv. 31-37)
}

Posiblemente, se refiere también a los textos normativos sobre José para rectificarlo en la modernidad temprana y las bromas, a veces poco doctrinales, que gasta a José en la obra. 


\section{CONCLUSIONES}

Como otros santos en el siglo XVI, San José es regenerado, como fruto del transformado fervor postridentino. Brotó así una nueva significación del esposo de María que borró su avanzada edad, su letargo, su torpeza y lo permutó en joven, dinámico y padre preocupado. Las características negativas del Patriarca provinieron de una tradición legendaria apócrifa que se extendió en el imaginario colectivo y, por supuesto, no fueron tan fácilmente erradicadas. Sor Juana heredó la nueva advocación a José que había prosperado en la Nueva España tan temprano como mediados del siglo XVI, pero las noticias legendarias e iconográficas pervivieron paralelamente. Además, la Décima Musa demostró en sus villancicos otro ejemplo de su irónico sentido de humor. La devoción femenina al santo se inició con Santa Teresa de Jesús $\mathrm{y}$, entre otras poblaciones, pareciera que el Patriarca podría ser atractivo a las mujeres: era humilde, casto, obediente, leal y jugó un papel secundario, casi insignificante, en las Sagradas Escrituras, todos atributos exigidos a las mujeres y especialmente a las religiosas, que tenían que lidiar con la jerarquía masculina eclesiástica. Quizás vieron en San José a un patriarca benéfico que había sufrido los mismos trances que ellas: ser desclasado.

Cuando Sor Juana redactó el juego de villancicos dedicado a San José para la Catedral de Puebla en 1690, tanto el género como la nueva imagen de José estaban en auge. Por un lado, se toleraban exhibiciones jocosas de versos y música como parte del Oficio divino. Y por el otro, José no era la Virgen María y se prestaba a una de las exhibiciones más alegres y populares de los villancicos. Aprovechando esta doble licencia, Sor Juana pudo tomar temas sacros y convertirlos en bromas, como la virginidad de María, el mutismo de José y sus ascendentes míticos negros. Congruente con el género y también con la reivindicación de San José, incluye -reivindicándolos a su vez-a personajes como Indio y Negro, que reflejaron una fiesta popular poblada por el rico tejido racial de la Nueva España.

\section{BIBLIOGRAFÍA}

Benassy-Berling, Marie-Cécile. Humanismo y religión en Sor Juana Inés de la Cruz. Trad. Laura López. México: UNAM, 1985.

Cantera, Jesús. "La figura de San José en el Arte". Mirabilia Ars 1 (2014/2): 35-94.

Echeverri, Alberto. “José de Nazaret, un creyente ensombrecido". Perseitas 6/1 (2018): 71-97. 
Ehrman, Bart D. y Zlatko Pleše. The Apocryphal Gospels: Texts and Translations. New York: Oxford University Press, 2011.

Krutitskaya, Anastasia. "Reutilización de formas tradicionales en los villancicos de Sor Juana. Olivar 18 (2012): 1-17.

Manzi, Ofelia y Patricia Grau-Dieckmann. "Los textos apócrifos en la iconografía Cristiana". Mirabilia 6 (jun-dez 2006): 20-33.

Méndez, Alfonso. "Notas a los villancicos". Obras completas de Sor Juana Inés de la Cruz, II, Villancicos y Letras Sacras. Ed. Alfonso Méndez. México: Fondo de Cultura Económica, 1995. 355-523.

Paz, Octavio. Sor Juana Inés de la Cruz o las trampas de la fe. México: Fondo de Cultura Económica, 1995.

Ribadeneyra, Pedro de. Flos Sanctorum, libro de las vidas de los Santos. Luis Sánchez, 1616.

Robinson, Beatriz. "Sor Juana Inés de la Cruz y la ensalada villanciquera, performancias carnavalescas de eficacia entretenimiento en la Nueva España". Chasqui: revista de literatura latinoamericana 40/1 (2011): 157-169.

Sánchez, Gabriela. "La fundación de cofradías de san José en la Nueva España”. Die Bedeutung des hl. Josef in der Heilgeschichte. Akten des IX. Internationalen Symposions über den heiligen Josef. Johannes Hattler y Germán Rovira, eds. Internationalen Mariologischen Arbeitskreis Kevelaer, Francfort del Meno, 2006, vol. II. 739-756.

Sor Juana Inés de la Cruz. Villancicos con que se solemnizaron, en la S. I. Catedral de la Puebla de los Ángeles, los Maitines del gloriosísimo Patriarca Señor San José, año de 1690. Obras completas de Sor Juana Inés de la Cruz, II, Villancicos y Letras Sacras. Ed. Alfonso Méndez. México: Fondo de Cultura Económica, 1995. 128-148.

Tenorio, Martha. Los villancicos de Sor Juana. México: El Colegio de México, 1999. 